\title{
Chagas Disease: Current Epidemiological Trends after the Interruption of Vectorial and Transfusional Transmission in the Southern Cone Countries
}

\author{
Alvaro Moncayo \\ Universidad de los Andes, Calle 70, no. 5-60, (204) Bogotá, Colombia
}

Chagas disease, named after Carlos Chagas who first described it in 1909, exists only on the American Continent. It is caused by a parasite, Trypanosoma cruzi, transmitted to humans by blood-sucking triatomine bugs and by blood transfusion.

Chagas disease has two successive phases, acute and chronic. The acute phase lasts 6 to 8 weeks. After several years of starting the chronic phase, 20\% to 35\% of the infected individuals, depending on the geographical area will develop irreversible lesions of the autonomous nervous system in the heart, esophagus, colon and the peripheral nervous system. Data on the prevalence and distribution of Chagas disease improved in quality during the 1980's as a result of the demographically representative cross-sectional studies carried out in countries where accurate information was not available. A group of experts met in Brasilia in 1979 and devised standard protocols to carry out countrywide prevalence studies on human $\mathrm{T}$. cruzi infection and triatomine house infestation.

Thanks to a coordinated multi-country program in the Southern Cone countries the transmission of Chagas disease by vectors and by blood transfusion has been interrupted in Uruguay in1997, in Chile in 1999, and in 8 of the 12 endemic states of Brazil in 2000 and so the incidence of new infections by T. cruzi in the whole continent has decreased by $70 \%$. Similar control multi-country initiatives have been launched in the Andean countries and in Central America and rapid progress has been recorded to ensure the interruption of the transmission of Chagas disease by 2005 as requested by a Resolution of the World Health Assembly approved in 1998.

The cost-benefit analysis of the investments of the vector control program in Brazil indicate that there are savings of US\$17 in medical care and disabilities for each dollar spent on prevention, showing that the program is a health investment with good return.

Since the inception in 1979 of the Steering Committee on Chagas Disease of the Special Program for Research and Training in Tropical Diseases of the World Health Organization (TDR), the objective was set to promote and finance research aimed at the development of new methods and tools to control this disease.

The well known research institutions in Latin America were the key elements of a world wide network of laboratories that received - on a competitive basis - financial support for projects in line with the priorities established.

It is presented the time line of the different milestones that were answering successively and logically the outstanding scientific questions identified by the Scientific Working Group in 1978 and that influenced the development and industrial production of practical solutions for diagnosis of the infection and disease control.

Key words: Chagas disease - Trypanosoma cruzi infection - control - interruption of transmission

Chagas disease, named after Carlos Chagas who first described it in 1909, exists only on the American Continent (Chagas 1909). It is caused by a flagellate parasite, Trypanosoma cruzi transmitted to humans by bloodsucking triatomine bugs and by blood transfusion.

The author was Secretary of the TDR Steering Committee on Chagas Disease from 1979-1997; Chief, Control of Trypanosomiasis and Leishmaniasis 1990-1998; and Manager of the TDR Task Force on Intervention Research on Chagas Disease from 1998 to 2001 at the World Health Organization, Geneva, Switzerland. Currently he is an Associate Researcher at the Universidad de los Andes, Bogotá, Colombia.

Fax:+57-1-332.4540. E-mail:moncayoa101@hotmail.com

Received 10 June 2003

Accepted 26 June 2003
Chagas disease has two successive phases, acute and chronic. The acute phase lasts 6 to 8 weeks. Once the acute phase subsides, most of the infected patients recover an apparent healthy status, where no organ damage can be demonstrated by the current standard methods of clinical diagnosis. The infection can only be verified by serological or parasitological tests. This form of the chronic phase of Chagas disease is called indeterminate form. Most patients remain in this form of the disease.

However, after several years of starting the chronic phase, $20 \%$ to $35 \%$ of the infected individuals, depending on the geographical area will develop irreversible lesions of the autonomous nervous system in the heart, esophagus, colon and the peripheral nervous system. The chronic phase lasts the rest of the life of the infected individual.

Chagas disease represents the first cause of cardiac lesions in young, economically productive adults in the endemic countries in Latin America. 
Thanks to a coordinated multi-country program in the Southern Cone countries the transmission of Chagas disease by vectors and by blood transfusion has been interrupted in Uruguay in 1997, Chile in 1999, and in 8 of the 12 endemic states of Brazil in 2000 and so the incidence of new infections by $T$. cruzi in the whole continent has decreased by more than $70 \%$. Similar control multi-country initiatives have been launched in the Andean countries and in Central America and rapid progress has been recorded to ensure the interruption of the transmission of Chagas disease by 2005 as requested by a Resolution of the World Health Assembly approved in 1998.

\section{MODES OF TRANSMISSION}

\section{Transmission through vectors}

Chagas disease is a zoonosis transmitted in natural foci or ecological units within a well-defined geographical environment. The ecological unit is composed of sylvan or domestic mammals and of sylvan Triatoma bugs, both infected with T. cruzi. Continuous transmission is assured with or without the involvement of human beings.

These conditions of transmission are present from latitude $42^{\circ} \mathrm{N}$ to latitude $40^{\circ} \mathrm{S}$ and so T. cruzi infection occurs from the South of the United States to the South of Argentina.

There are two stages of the human disease: the acute stage, which appears shortly after the infection; and the chronic stage, which may last several years and after several years of a silent asymptomatic period, $25 \%$ of those infected develop cardiac symptoms that may lead to chronic heart failure and sudden death, $6 \%$ develop digestive damage, mainly mega-colon and mega- esophagus, and 3\% will suffer peripheral nervous involvement (Coura 1983, 1985, Pereira 1985).

\section{Transmission via blood transfusion}

The rural-to-urban migration movements that occurred in Latin America in the decades of the1970's and 1980's changed the traditional epidemiological pattern of Chagas disease as a rural condition and transformed it into an urban infection that can be transmitted by blood transfusion.

In most countries in Latin America it is now compulsory to screen for infected blood in blood banks and systems have been established to do so.

\section{Methods and measurement of epidemiological trends in the continent from 1980 to 2000}

It should be noted that the prevalence and incidence of the disease as well as the mortality are constantly changing as a consequence of the impact of control programs, people migration and changes in socioeconomic conditions of the population.

Data on the decrease in frequency of new cases of infection by T. cruzi in the last decade as a result of vector control are presented below in the sections on the Subregional Initiatives for the Interruption of Transmission of Chagas Disease.

The estimation of the decrease in frequency rates of infection by $T$. cruzi in the period under study was made by comparing the age-specific prevalence rates of infection in a given age group in the period 1980-1985 (at the time when the cross sectional studies were carried out in the different countries) and the age-specific prevalence rates in the same age group in the period 1997-2000, i.e. 15 years later (Figs 1-6, Table VI).

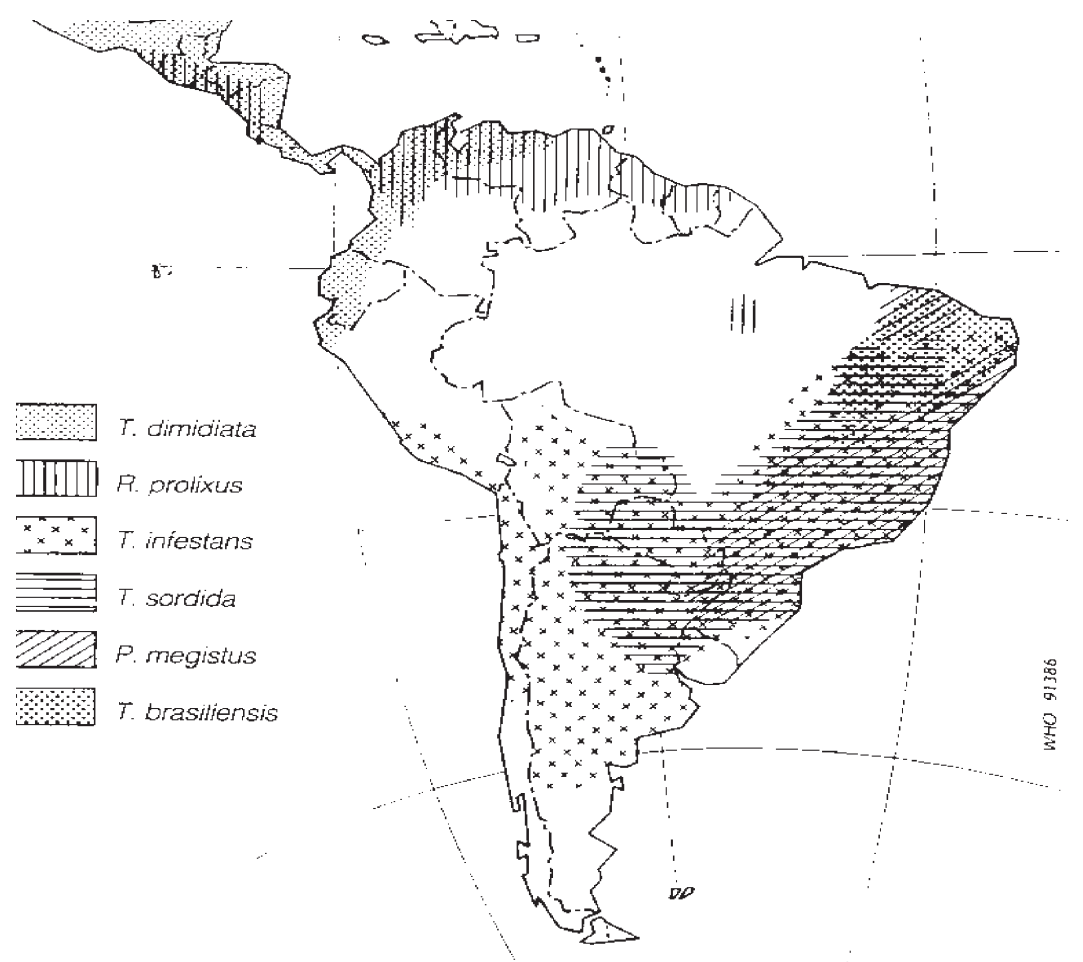




\section{Transmission through vectors}

Data on the prevalence and distribution of Chagas disease improved in quality during the 1980's as a result of the demographically representative cross-sectional studies carried out in countries where accurate information was not available. A group of experts met in Brasília in 1979 and devised standard protocols to carry out countrywide prevalence studies on human $T$. cruzi infection and triatomine house infestation.

These studies were carried out during the 1980's in collaboration with the Ministries of Health of Argentina, Bolivia, Brazil, Chile, Colombia, Costa Rica, Ecuador, El Salvador, Guatemala, Honduras, Panamá, Paraguay, Perú, Uruguay, and Venezuela. The accurate information obtained has made it easier for individual countries to plan and to evaluate the effectiveness of national control programs (PAHO 1974, Cedillos 1975, Marinkelle 1976, Zeledón et al. 1976, Cordova et al. 1980, Camargo et al. 1984, Reyes Lituma 1984, Ponce 1984, Lopez 1985, Schenone et al. 1985, Matta et al. 1985, Sousa 1985, Acquatella et al. 1987, Salvatella et al. 1989, Valencia 1990) (Table I).

On the basis of these individual countrywide cross sectional surveys it was estimated that the overall prevalence of human T. cruzi infection in the 18 endemic countries reaches 17 million cases. Some 100 million people ( $25 \%$ of all the inhabitants of Latin America) are at risk of contracting $T$. cruzi infection (Table II).

The incidence was estimated at 700 000-800 000 new cases per year and the annual deaths due to the cardiac form of Chagas disease at 45000 (UNDP/WORLD BANK/ WHO 1991)

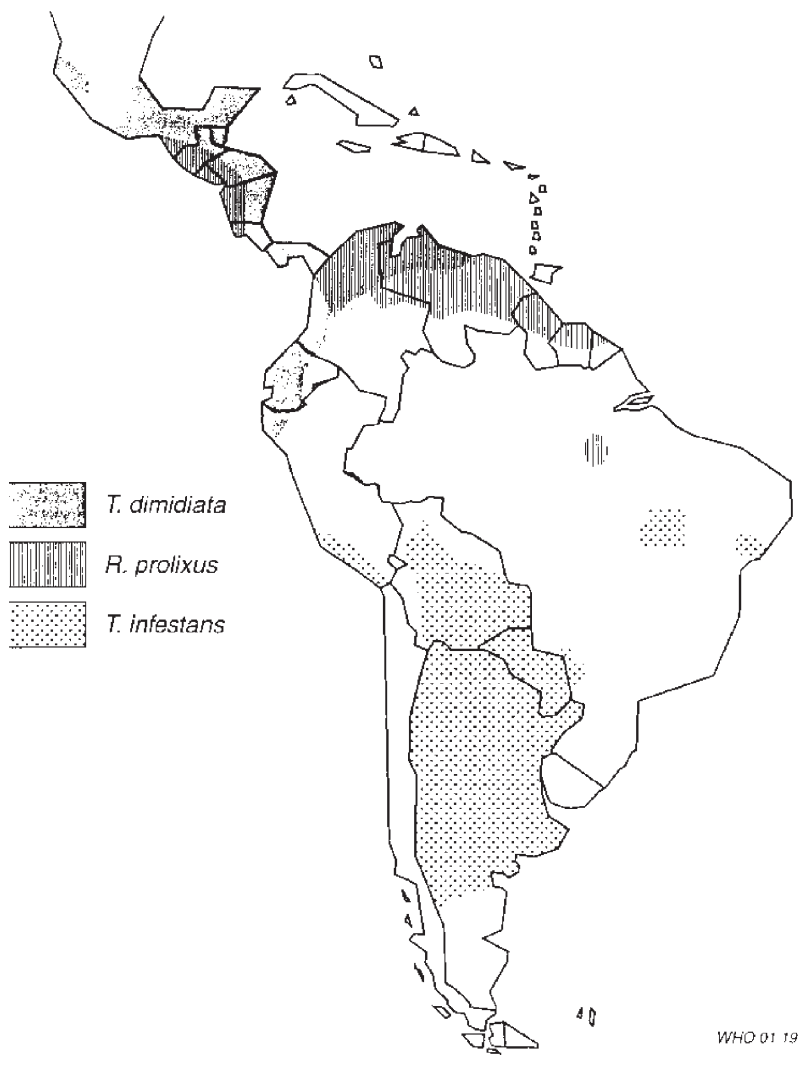

Source: Control of Chagas Disease, Second Report of a WHO Expert Committee, TRS 905, Geneva 2002, p. 44

Fig. 2: distribution of main vectors, 2000

TABLE I

Prevalence studies of human Tryapanosoma cruzi infection in Latin America, 1975-1985

\begin{tabular}{|c|c|c|c|c|c|}
\hline Country & Sample size & Percentage infected & Year & Remarks & Reference \\
\hline \multicolumn{6}{|l|}{ Group 1} \\
\hline $\begin{array}{l}\text { Argentina } \\
\text { Brazil } \\
\text { Bolivia } \\
\text { Chile } \\
\text { Honduras } \\
\text { Paraguay } \\
\text { Uruguay } \\
\text { Venezuela }\end{array}$ & $\begin{array}{r}\text { ND } \\
1352917^{a} \\
56000^{a} \\
13514^{a} \\
3802^{a} \\
4037^{a} \\
5924^{a} \\
5696^{a}\end{array}$ & $\begin{array}{l}10 \\
4.2 \\
24 \\
16.9 \\
15.2 \\
21.4 \\
3.4 \\
3\end{array}$ & $\begin{array}{l}1976 \\
1980 \\
1980 \\
1985 \\
1984 \\
1983 \\
1985 \\
1983\end{array}$ & $\begin{array}{l}\text { Estimation } \\
\text { Country-wide } \\
\text { Country-wide } \\
\text { Country-wide } \\
\text { Country-wide } \\
\text { Country-wide } \\
\text { Country-wide } \\
\text { Age group }<24\end{array}$ & $\begin{array}{l}\text { PAHO } 1974 \\
\text { Camargo } 1984 \\
\text { Valencia } 1990 \\
\text { Schenone } 1985 \\
\text { Ponce } 1984 \\
\text { Lopez } 1985 \\
\text { Salvatella } 1989 \\
\text { Aquatella } 1987\end{array}$ \\
\hline \multicolumn{6}{|l|}{ Group 2} \\
\hline $\begin{array}{l}\text { Ecuador } \\
\text { Colombia } \\
\text { Costa Rica } \\
\text { México } \\
\text { Perú }\end{array}$ & $\begin{array}{r}532 \\
20000 \\
1420 \\
\text { ND } \\
92\end{array}$ & $\begin{array}{l}10.7 \\
30 \\
11.7 \\
\text { ND } \\
9.8\end{array}$ & $\begin{array}{l}1984 \\
1975 \\
1976\end{array}$ & $\begin{array}{l}\text { Endemic areas } \\
\text { Endemic areas } \\
\text { Endemic areas } \\
\text { Age group 0-6 }\end{array}$ & $\begin{array}{l}\text { Reyes Lituma } 1984 \\
\text { Marinkelle } 1976 \\
\text { Zeledón } 1976 \\
\text { Cordova } 1980\end{array}$ \\
\hline \multicolumn{6}{|l|}{ Group 3} \\
\hline $\begin{array}{l}\text { El salvador } \\
\text { Guatemala } \\
\text { Nicaragua } \\
\text { Panamá }\end{array}$ & $\begin{array}{r}524 \\
3952 \\
\mathrm{ND} \\
1770\end{array}$ & $\begin{array}{l}20 \\
16.6 \\
\text { ND } \\
17.7\end{array}$ & $\begin{array}{l}1975 \\
1982\end{array}$ & $\begin{array}{l}\text { Rural areas } \\
\text { Country-wide } \\
\text { Endemic areas }\end{array}$ & $\begin{array}{l}\text { Cedillos } 1975 \\
\text { Matta } 1985 \\
\text { Sousa } 1985\end{array}$ \\
\hline
\end{tabular}

a: demographic sample statistically representative of the country's population; ND: no data 
The endemic countries can be divided into 3 groups according to several indicators such as: number of confirmed human cases; prevalence of seropositive tests in blood donors and population samples; and the presence of infected vectors and reservoirs. The main factors on which these criteria are based are the following: magnitude of the transmission; quantity and quality of the available epidemiological information; and existence or absence of coordinated actions towards the control of this disease (UNDP/WORLD BANK/WHO 1987).

Group 1 - The countries of this group present high prevalence of human T. cruzi infection and high triatomine house infestation rates, which have induced the national health authorities to establish control activities through vertical programs or, more recently, within the context of primary health care (PHC) strategies. Argentina, Bolivia, Brazil, Chile, Honduras, Paraguay, Uruguay and Venezuela are included in this group.

Group 2 - All the countries included in this group show evidence of intradomiciliary transmission, with a clear association between $T$. cruzi infection and electrocardiograph alterations as well as other pathologies attributable to Chagas disease. No formal control programs have yet been established in these countries. Colombia, Costa Rica, Ecuador México and Perú belong to this group.

Group 3 - These countries show evidence of domiciliary transmission but more accurate epidemiological data are needed to support a clear correlation between T. cruzi infections and clinical records. In all these countries, the acute phase of Chagas disease is frequently observed, and recent serological data indicate that the prevalence of seropositive reactions to $T$. cruzi antigens is high. El Salvador, Guatemala, Nicaragua and Panamá, are included in this group.

\section{Transmission through blood transfusion}

The figures in Table III show the extent of the problem of transmission via blood transfusion in some selected cities of the continent between 1980 and 1989 (Schmunis 1991). While it varies between 1.3 and $51 \%$, the prevalence of T. cruzi infection in blood is much higher than that of hepatitis or HIV infection.

The transmission of Chagas disease via blood transfusion is a real threat even for countries where the disease is not transmitted by vector, such as the US and Canada, where cases of acute Chagas disease have been recently documented (Grant et al. 1989, Nickerson et al. 1989, Kichkoff 1989).

The prevalence of infected blood samples in the Southern Cone countries has decreased as shown by the consistently decreasing trend in all 6 countries of this sub-region since 1994 (Table IV).

\section{ECONOMIC IMPACT}

The economic impact of the disease during the chronic stage is very high as shown by data from Brazil (Sucam 1987).

If we consider that about $30 \%$ of the infected persons will develop severe cardiac and digestive lesions such as cardiac arrhythmia (75000 cases), mega-esophagus (45 000 cases) and mega-colon (30 000 cases) per year,

TABLE II

Prevalence of human Trypanosoma cruzi infection in Latin America, 1975-1985

\begin{tabular}{|c|c|c|c|}
\hline Country & $\begin{array}{l}\text { Population at risk } \\
\text { (thousands) }\end{array}$ & $\begin{array}{l}\text { Percentage of } \\
\text { total population }\end{array}$ & $\begin{array}{l}\text { Number of infected } \\
\text { persons (thousands) }\end{array}$ \\
\hline \multicolumn{4}{|l|}{ Group 1} \\
\hline $\begin{array}{l}\text { Argentina } \\
\text { Brazil } \\
\text { Bolivia } \\
\text { Chile } \\
\text { Honduras } \\
\text { Paraguay } \\
\text { Perú } \\
\text { Uruguay } \\
\text { Venezuela }\end{array}$ & $\begin{array}{r}6900 \\
41054 \\
1800 \\
11600 \\
1824 \\
1475 \\
6766 \\
975 \\
12500\end{array}$ & $\begin{array}{l}23 \\
32 \\
32 \\
63 \\
47 \\
31 \\
39 \\
33 \\
72\end{array}$ & $\begin{array}{r}2640 \\
6180 \\
1300 \\
1460 \\
300 \\
397 \\
621 \\
37 \\
1200\end{array}$ \\
\hline \multicolumn{4}{|l|}{ Group 2} \\
\hline $\begin{array}{l}\text { Colombia } \\
\text { Costa Rica } \\
\text { Ecuador } \\
\text { México }\end{array}$ & $\begin{array}{r}3000 \\
1112 \\
3822 \\
\text { ND }\end{array}$ & $\begin{array}{r}11 \\
45 \\
41 \\
\text { ND }\end{array}$ & $\begin{array}{r}900 \\
130 \\
30\end{array}$ \\
\hline \multicolumn{4}{|l|}{ Group 3} \\
\hline $\begin{array}{l}\text { El Salvador } \\
\text { Guatemala } \\
\text { Nicaragua } \\
\text { Panamá }\end{array}$ & $\begin{array}{r}2146 \\
4022 \\
\text { ND } \\
898\end{array}$ & $\begin{array}{r}45 \\
54 \\
\mathrm{ND} \\
47\end{array}$ & $\begin{array}{r}900 \\
1100\end{array}$ \\
\hline Total & 99895 & 25 & 17395 \\
\hline
\end{tabular}

ND: no data 
the estimated costs for pacemaker implants and corrective surgery (average US\$5 000) would amount to approximately US\$750 million per year, which would be enough for the improvement or construction of more than 700000 rural dwellings at a minimum estimated cost of US\$1 000 each in Brazil.

Between 1979 and 1981, 14022 deaths were due to Chagas disease in Brazil which represented approximately 259152 years of potential life lost (YPLL) before the age of retirement. Assuming that all the patients were unqualified rural workers only and that the minimum daily wage was at the time US\$2.5, the total economic loss due to premature deaths would amount to US\$237 million.

\section{FEASIBILITY OF INTERRUPTION OF TRANSMISSION}

The tools for interrupting the domestic cycle of T. cruzi transmission, such as chemical control, housing improvement, and health education are available. In fact, the prevalence of the infection has decreased in countries that have consistently applied control measures. For example, after 20 years of control programs in Argentina, positive serology in 18 -year-old males has significantly decreased since 1980, and the number of reported new acute cases decreased since the 1970's (Segura 1985). In

TABLE IV

Prevalence rates x 100 of blood samples infected by Trypanosoma cruzi, Southern Cone countries, 1994-1999

\begin{tabular}{lrrrrrr}
\hline Country & 1994 & 1995 & 1996 & 1997 & 1998 & 1999 \\
\hline Argentina & 5.6 & ND & 4.9 & 3.7 & 4.3 & 4.2 \\
Brazil & ND & ND & ND & ND & ND & 2.8 \\
Bolivia & 14.8 & 20.2 & 13.7 & ND & ND & ND \\
Chile & 1.2 & ND & ND & 1.0 & 0.96 & 0.9 \\
Paraguay & 5.3 & 4.5 & 5.8 & 4.0 & 3.7 & ND \\
Uruguay & 0.8 & 0.6 & 0.5 & 0.6 & 0.6 & ND
\end{tabular}

ND: no data; Source: PAHO 1997, 1999

TABLE III

Prevalence of Trypanosoma cruzi infected blood in blood banks of selected countries, 1972-1990

\begin{tabular}{|c|c|c|c|}
\hline Country & Number of samples tested & Percentage positive & Reference \\
\hline \multicolumn{4}{|l|}{ Group 1} \\
\hline \multicolumn{4}{|l|}{ Argentina } \\
\hline Buenos Aires (1987) & 58284 & 4.9 & Perez and Segura 1989 \\
\hline Santiago del Estero (1987) & 2003 & 17.6 & Perez and Segura 1989 \\
\hline Cordoba (1982) & 2441 & 8.4 & Perez and Segura 1989 \\
\hline \multicolumn{4}{|l|}{ Bolivia } \\
\hline Santa Cruz (1990) & 205 & 51 & Carrasco 1990 \\
\hline \multicolumn{4}{|l|}{ Brazil } \\
\hline Brasília (1984) & 2413 & 14.6 & Pereira 1984 \\
\hline Paraná (1987) & 3000 & 4.8 & Marzochi 1981 \\
\hline São Paulo (1982) & 56902 & 2.9 & Dias and Brener 1984 \\
\hline \multicolumn{4}{|l|}{ Chile } \\
\hline Santiago (1983) & 214 & 3.7 & Liendo 1985 \\
\hline Vicuna (1983) & 62 & 14.5 & Liendo 1985 \\
\hline \multicolumn{4}{|l|}{ Honduras } \\
\hline Tegucigalpa (1987) & 1225 & 11.6 & Ponce and Ponce 1987 \\
\hline \multicolumn{4}{|l|}{ Paraguay } \\
\hline Asunción (1972) & 562 & 11.3 & Reports Ministry of Health \\
\hline \multicolumn{4}{|l|}{ Uruguay } \\
\hline Paysandú (1983-84) & 445 & 4.7 & Franca 1986 \\
\hline Salto $(1983-84)$ & 71 & 4.2 & Franca 1986 \\
\hline Tacuarembo (1983-84) & 699 & 7.7 & Franca 1986 \\
\hline \multicolumn{4}{|l|}{ Venezuela } \\
\hline Various cities & 195476 & 1.3 & Schmunis 1991 \\
\hline \multicolumn{4}{|l|}{ Group 2} \\
\hline \multicolumn{4}{|l|}{ Colombia } \\
\hline Bogota (1990) & 1128 & 2.5 & Guhl 1987 \\
\hline Cucuta (1987) & 491 & 7.5 & Guhl 1987 \\
\hline \multicolumn{4}{|l|}{ Costa Rica } \\
\hline San José (1985) & 602 & 1.6 & Urbina 1991 \\
\hline \multicolumn{4}{|l|}{ Ecuador } \\
\hline Guayaquil (1971) & 1054 & 3.2 & Reports Ministry of Health \\
\hline \multicolumn{4}{|l|}{ Perú } \\
\hline Tacna (1972) & 329 & 12.9 & Reports Ministry of Health \\
\hline \multicolumn{4}{|l|}{ México } \\
\hline Puebla (1986) & 200 & 17.5 & Velasco Castrejon 1986 \\
\hline
\end{tabular}

Source: Schmunis 1991 
Brazil, transmission by vector has been interrupted in the whole state of São Paulo since the mid-1970's. Decreasing rates of seropositive school children has paralleled the above control efficacy: in 1976, the incidence rate was $60 \%$ and in 1983 it dropped to $0 \%$ (Souza et al. 1984).

Transmission through transfusion could be prevented if blood is screened by serology and positive units are discarded. In most countries of the region, serology for T. cruzi is mandatory for blood donors.

Available knowledge therefore indicates that the most common ways of transmission of human T. cruzi infection could be interrupted by: (1) implementation of vector control activities in houses in order to first reduce and then eliminate the vector borne transmission of T. cruzi; and (2) strengthening the ability of blood banks to prevent transmission of Chagas disease and other diseases transmitted by blood transfusion through development and implementation of a policy for human blood use.

\section{CURRENT CONTROL PROGRAMS}

The traditional vertical control programs in the Latin American countries have focused on the spraying of insecticides on houses and household annexes and buildings. National control programs aimed at the interruption of the domestic and peridomestic cycles of transmission involving vectors, animal reservoirs and man are feasible and have proven to be very effective. Reaching the goal of eliminating vector borne transmission is more feasible in areas where the vector is domiciliated like Triatoma infestans and Rhodnius prolixus.

Eight countries of the Americas have active control programs that combine insecticide spraying with health education. The common pattern of the vertical, centralized control programs follows several operational steps or phases, namely: (a) preparatory phase for mapping and general programming of activities and estimation of resources; (b) attack phase during which a first massive insecticide spraying of houses takes place and is followed by a second spraying 6 to 12 months later, with further evaluations for selective re-spraying of re-infested houses; and (c) surveillance phase for the detection of residual foci of triatomines after the objective of the attack phase has been reached. In this last phase, the involvement of the community and the decentralization of residual control activities are essential elements.
A prime example is the program which has been operating in Brazil since 1975 when 711 Brazilian municipalities had triatomine-infested dwellings that were the objective of the control program. Ten years later, in 1986, only 186 municipalities remained infested. This represents a successful accomplishment of the program objectives in $74 \%$ of the originally infested municipalities. In 1993 there were only 83 municipalities infested which represents a reduction of $86 \%$. In 1983, 84334 T. infestans bugs were captured by field workers but in 1998 only 485 insects were found in the whole country.

In large parts of the Southern Cone countries, programs have entered the surveillance phase characterized by monitoring of house infestation, and where necessary, focal spraying.

\section{Program costs and cost-effectiveness of control interventions}

The countries of the Southern Cone Initiative have spent more that US\$345 millions of national funds from their national budgets to finance the vector control activities in their territories. Table V shows the totals of these amounts by country and by year since the launching of the initiative in 1991.

The Ministry of Health of Brazil carried out a study aimed at the analysis of the cost-effectiveness and costbenefit of the Chagas Disease Control Program in Brazil. Due to the chronic nature of the disease and the protracted period of evolution, a period of 21 years was chosen for the analysis. The time interval from 1975 to 1995 includes data from different sources of information that were used to carry out this evaluation (Akhavan 1997).

Effectiveness was defined using various parameters, but the main one was the measurement of burden of disease prevented in DALY's (disability-adjusted lifeyears). From 1975 to 1995, the program (excluding blood banks) prevented an estimated $89 \%$ of potential disease transmission, preventing 2, 339, 000 new infections and 337000 deaths. This translated into the prevented loss of 11, 486, 000 DALY's, 31\% from averted deaths, and 69\% from averted disability, showing the large role of disability in the overall burden of disease caused by Chagas disease.

The estimated benefits (expenditures prevented) of the program (excluding blood banks) were US $\$ 7,500,000,000,63 \%$ of the savings being health care expenditures and $37 \%$ social security expenditures

TABLE V

National funds invested in the interruption of transmission of Chagas disease in the Southern Cone countries 1991-1999 (US\$ thousands)

\begin{tabular}{lrrrrrrr}
\hline Country & $1991-1994$ & 1995 & 1996 & 1997 & 1998 & 1999 & Total \\
\hline Argentina & 52000 & 18000 & 18000 & 14000 & 16000 & 13000 & 131000 \\
Bolivia & 83 & 430 & 706 & 2940 & 4410 & 4500 & 13069 \\
Brazil & 38420 & 48000 & 28000 & 35000 & 15000 & 20000 & 184420 \\
Chile & 1200 & 300 & 1000 & 600 & 500 & 500 & 4100 \\
Paraguay & 224 & 1250 & 1252 & 2019 & 2400 & 1200 & 10345 \\
Perú & 0 & 0 & 0 & 2570 & ND & 2000 & 4570 \\
Uruguay & 179 & 74 & 74 & 74 & 75 & 100 & 676 \\
\hline Total & 94106 & 68054 & 49039 & 57203 & 38385 & 41300 & 348087 \\
\hline
\end{tabular}

Source: reports by the Ministries of Health to the Meetings of the Intergovernment Commission, 1991-2000 
(disability insurance and retirements).

The cost-effectiveness analysis demonstrated that for each US\$39 spent on the program, 1 DALY was gained. This places the program and its activities in the category of interventions with a very high cost-effectiveness. The results of the cost-benefit analysis indicated savings of US\$17 for each dollar spent on prevention, also indicating that the program is a health investment with good return. The analysis of other diseases with socio-economic causes demonstrated that the decline in Chagas disease infection rates is due to the preventive activities, and not due to general improvement in life conditions.

\section{EPIDEMIOLOGICAL IMPACT}

The average reduction of incidence in the Southern Cone countries is $94 \%$ as shown in Table IV. By cutting the transmission of the disease in the countries of the sub-region in this proportion, the incidence of Chagas disease in the whole of Latin America has been reduced by $70 \%$ : the incidence of cases was reduced from an estimated 700000 new cases per year in the whole region in 1983 to less than 200000 new cases per year in 2000 . Also the annual number of deaths dropped from more than 45000 to 22000 . The number of endemic countries was 18 in 1983 and in 2000 it was reduced to 15 , as shown in Table VII (WHO 2002).

The intradomiciliary infestation by $T$. infestans has been eliminated in 8 out of the 12 endemic states of Brazil in 2000, in Chile in 1999, and in Uruguay in 1997 (Figs 1, 2).

At present, the major challenge is to ensure the sustainability of this program in an epidemiological context with very low $T$. cruzi infection rates and a politicalinstitutional context of health sector reforms, where the decentralization of operations may result in the risk of the activities losing priority. The new institutional order requires that Chagas disease control be integrated into other services, and programs, and become part of a broader scheme for meeting the health needs of the population. In these circumstances the integrated activities must sustain the significant progress so far achieved in the way of elimination of Chagas disease.

The model implemented in the Southern Cone has already been adapted to the other two initiatives in the Andean Countries and Central America (WHO 2002).

A detailed epidemiological and entomological analysis country by country follows to substantiate the evaluation of the impact of the control programs in interrupting the transmission of Chagas disease.

\section{INITIATIVE OF THE SOUTHERN CONE COUNTRIES:} EPIDEMIOLOGICAL TRENDS

In Brasília in June 1991, the ministers of Health of Argentina, Brazil, Bolivia, Chile, Paraguay, and Uruguay launched the initiative for the elimination of transmission of Chagas disease by the year 2000 (Mercosur 1991). Since the vector of T. cruzi, T. infestans, is intradomiciliary in these countries, sustained implementation of control measures have successfully interrupted transmission of Chagas disease as indicated in Tables VI and VII.

In these countries there were 11 millions of infected persons and 50 millions were at risk. This represented $62 \%$ of the prevalence of infected individuals of the whole continent.

Chagas disease is recognized as an important public health problem and is given increased priority for control, as demonstrated by the above government initiative that has been very successful. By cutting the transmission of this disease in the countries of the Southern Cone the incidence of Chagas disease will be reduced by $70 \%$ in the whole of Latin America.

Technical representatives of each Ministry were designated to form an Intergovernmental Commission in charge of implementation and evaluation of the control programs. The Pan American Health Organization (PAHO) was appointed as the Secretariat of this Commission.

A program guide has been designed by the Commission incorporating revisions submitted by the professional staff of the control programs and has been used for the development of the country programs. The proposed plans for Argentina, Brazil, Bolivia, Chile, Paraguay, and Uruguay are approved on a yearly basis by their respective governments.

\section{TABLE VII}

Changes in epidemiological parameters due to interruption of transmission and decrease of incidence, 1990-2000

\begin{tabular}{lll}
\hline $\begin{array}{l}\text { Epidemiological } \\
\text { parameters }\end{array}$ & 1990 & 2000 \\
\hline $\begin{array}{l}\text { Annual deaths } \\
\text { Annual new cases }\end{array}$ & 700000 & 21000 \\
Distribution & 18 countries & $\begin{array}{l}\text { 15 countries } \\
\text { (transmission } \\
\text { interrupted in Uruguay } \\
\text { in 1997, Chile in 1999, and } \\
\text { most of Brazil in 2000) }\end{array}$ \\
& &
\end{tabular}

Source: WHO 2002

TABLE VI

Human infection by Trypanosoma cruzi (Rates x 100) and reduction of incidence (\%), Southern Cone Initiative, 1980-2000

\begin{tabular}{lcccc}
\hline Country & $\begin{array}{c}\text { Age group } \\
\text { (years) }\end{array}$ & $\begin{array}{c}\text { Prevalence of infection } \\
\text { in 1980-1985 }\end{array}$ & $\begin{array}{c}\text { Prevalence of infection } \\
\text { in 2000 }\end{array}$ & $\begin{array}{c}\text { Reduction } \\
\text { in age group }\end{array}$ \\
\hline Argentina & 18 & 5.8 (Segura 1985) & 1.2 (WHO 1996) & $\mathbf{8 0 . 0}$ \\
Brazil & $0-4$ & 5.0 (Camargo 1984) & 0.12 (WHO 2000b) & $\mathbf{9 8 . 0}$ \\
Chile & $0-10$ & 5.4 (Schenone 1985) & 0.38 (WHO 2000a) & $\mathbf{9 4 . 0}$ \\
Paraguay & 18 & 9.3 (Cerisola 1972) & 3.9 & $\mathbf{6 0 . 0}$ \\
Uruguay & $6-12$ & 2.5 (Salvatella 1989) & 0.06 (WHO 1998a) & $\mathbf{9 9 . 0}$ \\
\hline
\end{tabular}

$a$ : reports to the 10th Meeting of the Intergovernment Commission of the Southern Cone Initiative, Montevideo 2001 
There have been 12 meetings of the Intergovernmental Commission held in Buenos Aires, Argentina (1992), Santa Cruz, Bolivia (1993), Montevideo, Uruguay (1994), Asuncion, Paraguay (1995), Porto Alegre, Brazil (1996), Santiago, Chile (1997), Buenos Aires (1998), Tarija, Bolivia (1999), Rio de Janeiro, Brazil (2000), Montevideo, Uruguay (2001), and Santiago, Chile (2002) at which the field activities of the country programs were reviewed annually using common indicators to assess impact and costeffectiveness of the national programs.

Current data (WHO 1994, 1995, 1996, 1997, 1998a, 1999a, 2000a, b) on disinfestations of houses, blood bank screening, and incidence of infection in the under-5 years age group, indicate that the vector borne and transfusional transmission of Chagas disease were interrupted in Uruguay in 1997, in Chile in 1999, and in Brazil in 2000. Argentina, Bolivia and Paraguay are expected to be free of transmission by 2005 .

Chagas disease has been targeted for elimination by the World Health Assembly in Resolution WHA51.14 approved in May 1998 (WHO 1998b).

\section{ARGENTINA (FIG. 3)}

The area of transmission covered $60 \%$ of the country north of parallel $44^{\circ}$. The main vector is $T$. infestans.

As of 1999, the whole endemic area of the country has been placed under entomological surveillance, the most advanced phase of the elimination process. In 1980 the average house infestation rate for the country as a whole was $30 \%$; in 1998 it was $1.2 \%$; and in 2002 it dropped to $1 \%$ which is equivalent to $98 \%$ reduction in house infestation by the main vector.

The seroprevalence rates for the whole country for the age group 0 - 4 years is $0.9 \%$ which confirms the very

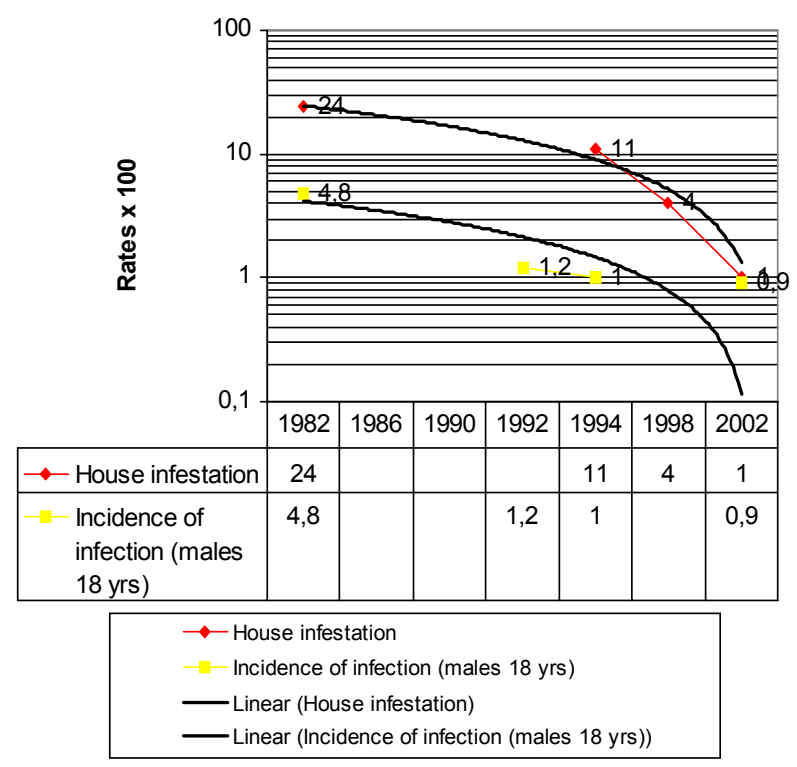

Source: WHO, Weekly Epidemiological Record, Geneva, 1996, 71: 2, 12-15, and Report Ministry of Health 2002

Fig. 3: Argentina: interruption of transmission of Chagas disease, 1982-2002, Rates x 100 low number of acute cases among children in this age group. In the age group $0-14$ years the rate is $1.9 \%$. In the age group of 18 year old males the seroprevalence rates have dropped from $5.8 \%$ in 1981 to $1 \%$ in 1993 and $0.5 \%$ in 2002. The interruption of vectorial transmission has been achieved in 10 of the 13 endemic provinces of the country (Ministerio de Salud 2002).

Finally, there is $100 \%$ coverage of the blood donations screened against Chagas disease in the blood banks of the public sector and $80 \%$ coverage in the private ones (WHO 1996).

\section{BOLIVIA}

The endemic area covers $80 \%$ of the extension of the country which corresponds to 7 of the 9 departments. $T$. infestans is the main vector. In 1982 it was estimated a total of 1,300,000 infected persons and in $26 \%$ of them electrocardiograph alterations were observed. The house infestation rate for the whole country was $41.2 \%$ in that year and the infection rate in the vectors was $30 \%$. Infection rates of more than $50 \%$ have been reported in blood donors in Santa Cruz (Carrasco 1990).

Data on serological prevalence shows a rate of $28.8 \%$ in the general population while in the age group of $0-4$ year is $22 \%$ in Cochabamba but $0 \%$ in Potosi where there is an active vector control program. In Tupiza another department where there is an active control program, the house infestation rate is $0.8 \%$ (PAHO 1998b).

The goal for interruption of transmission has been set for 2005 .

\section{BRAZIL (FIG. 4)}

The main vector was T. infestans. Other 2 common species, T. brasiliensis and Panstrongilus megistus are less important in disease transmission.

In 1975 the endemic area comprised 3,600,000 or 36\% of the total extension of the country and the most extensive endemic area on the continent. This area included 2493 municipalities in the states of Alagoas, Bahia, Ceará, Espírito Santo, Goiás, Piauí, Rio de Janeiro, Rio Grande do Norte, Rio Grande do Sul, Sergipe, Tocantins, and the Federal District of Brasília. At the present only the states of Bahia, Tocantins, Goiás and Rio Grande do Sul are still considered infested by the main vector.

House infestation due to $T$. infestans has been reduced from 166000 insects captured in the endemic areas by the control program in 1975 to 611 insects captured in 1999 in the same areas which corresponds to a reduction of $99.7 \%$ of the infestation by this vector. This represents an average of 1 insect per 10000 houses surveyed, i.e. an infestation rate far below the minimum required for effective transmission of the parasite into new patients.

The proportion of infected individuals that will develop cardiac pathology is variable but electrocardiograph tracings compatible with chagasic cardiac lesions is found in $15-30 \%$ of seropositive individuals after 15-20 years of infection. Mega viscera and other digestive lesions are found in $10 \%$ of the infected population.

The prevalence of human T. cruzi infection in the 7-14 year group in 1999 was $0.04 \%$ as compared with $18.5 \%$ in 1980. This represents a $99.8 \%$ reduction of incidence of infection in this age group. 


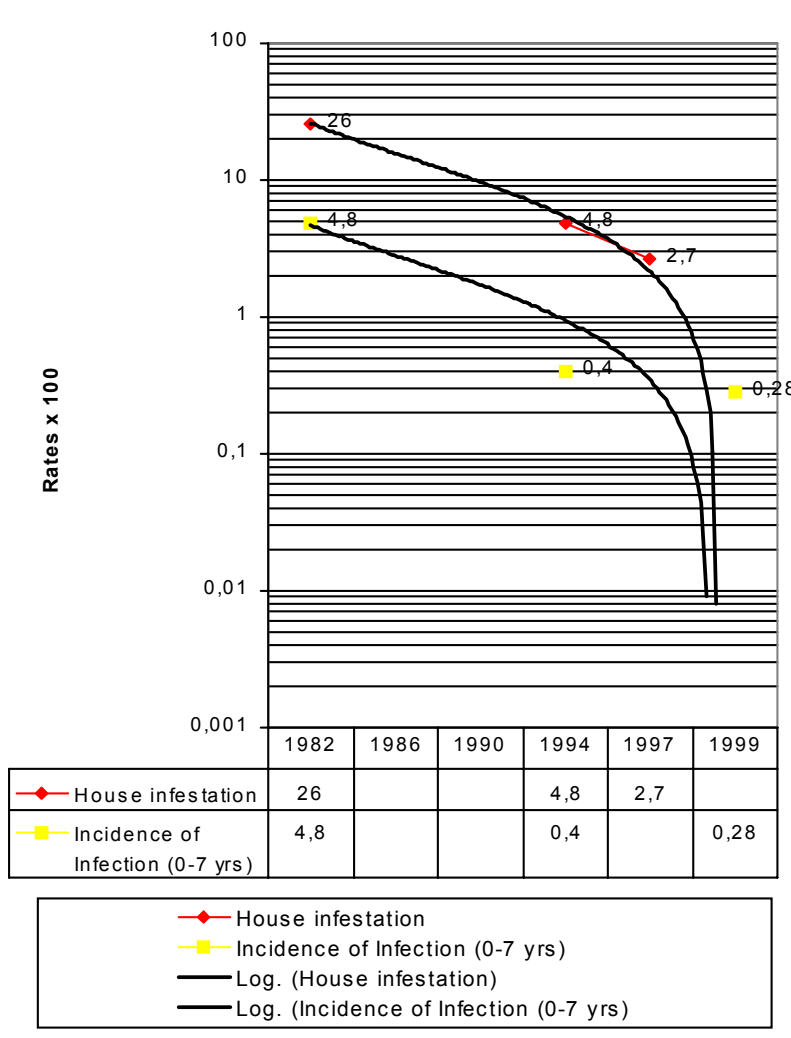

Source: Weekly Epidemiological Record, WHO, Geneva, 1997, 72: 1/2, p.1-5, and Report of the Intergovernement Comission 1999

Fig. 4: Brazil: interruption of transmission of Chagas disease, 19821999, Rates x 100

Results of serological tests in a limited number of samples in the population of the 0-4 year group in 1999 indicate that the seroprevalence in this age group is $0 \%$ which can be interpreted as a proof of the interruption of vectorial transmission of Chagas disease in Brazil.

The above data confirms the interruption of transmission of Chagas disease by T. infestans vectors in Brazil. Based on the above epidemiological and entomological data an international commission in charge of evaluating the interruption of vectorial transmission in this country will issue a certification of 8 out of the 12 endemic states of the country as free of transmission in 2000 (WHO 1997, 2000b, PAHO 1998a, b).

\section{CHILE (FIG. 5)}

The vector responsible for disease transmission was T. infestans which has been eliminated from human dwellings and hence the transmission has been interrupted.

The overall infestation rate for the country has been reduced from $3.2 \%$ in 1994 to $0.14 \%$ in 1999 , a reduction of $99.8 \%$ in the last 3 years. In 1999 there were just 26 T. infestans insects were captured in the interior of dwellings of the endemic areas in the whole country which represents 2.5 insects in every 1000 houses, an infestation rate far below the threshold required for effective transmission of the parasite to new persons.
The infection rate in the age group 0-4 years in 1999 was $0.016 \%$ which represents a reduction of $98.5 \%$ as compared to $1.12 \%$ that was found in the same age group in 1995 .

The screening in blood banks in the endemic areas is mandatory since 1996 and the prevalence of infected samples has been reduced to $0.5 \%$.

An independent commission visited the endemic areas of the country in November 1999 and based on the above data certified the interruption of vectorial transmission (WHO 1999a, 2000a).

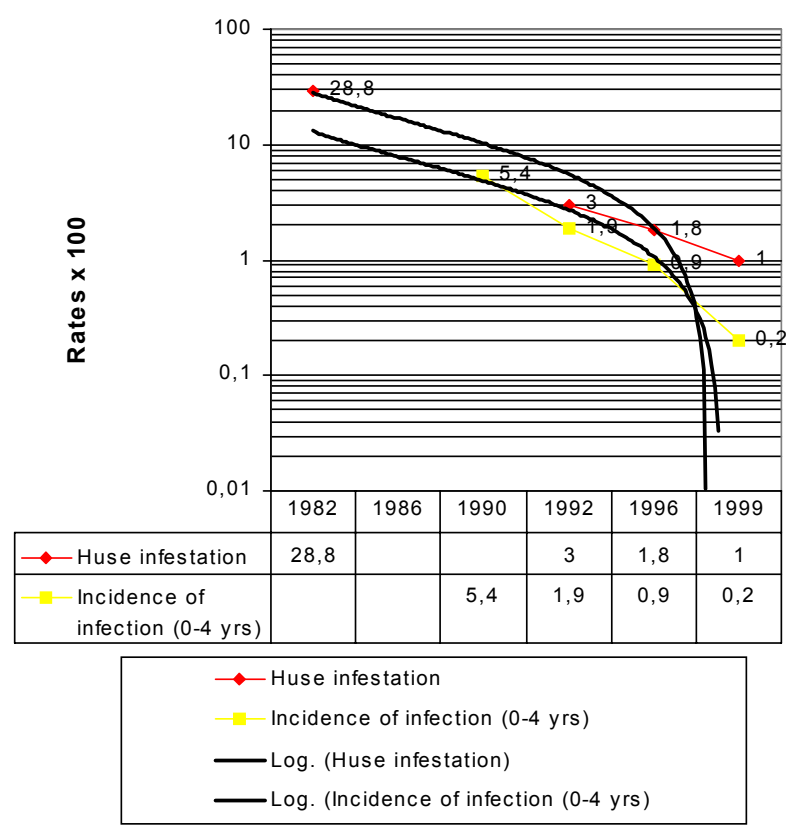

Source: WHO, Weekly Epidemiological Record, Geneva, 1999, 74: 2, 9-11, and Report of the Certification Commission, November 1999

Fig. 5: Chile: interruption of transmission of Chagas disease, 19822000, Rates x 100

\section{PARAGUAY (FIG. 6)}

The main vector is $T$. infestans. Chagas disease is endemic in all rural areas of the country and the house infestation rate in 1982 varied from $10 \%$ in the department of Misiones to $20 \%$ in Cordillera.

In a serological survey carried out in 1997 in a representative sample (940 individuals) of children less than 13 years old in marginal areas of the capital city of Asuncion a significant decrease of prevalence rates was observed in all age groups when compared with data of 1972.

Rural/urban migration to these marginal areas of Asuncion comes mainly from Paraguari, Cordillera and Central which have the highest domiciliary infestation rates by triatomines. However, the fact of the 0 prevalence rate in the age group of less than 4 year old indicate interruption of transmission by triatomines in the urban areas of the capital (PAHO 1998a, b). 


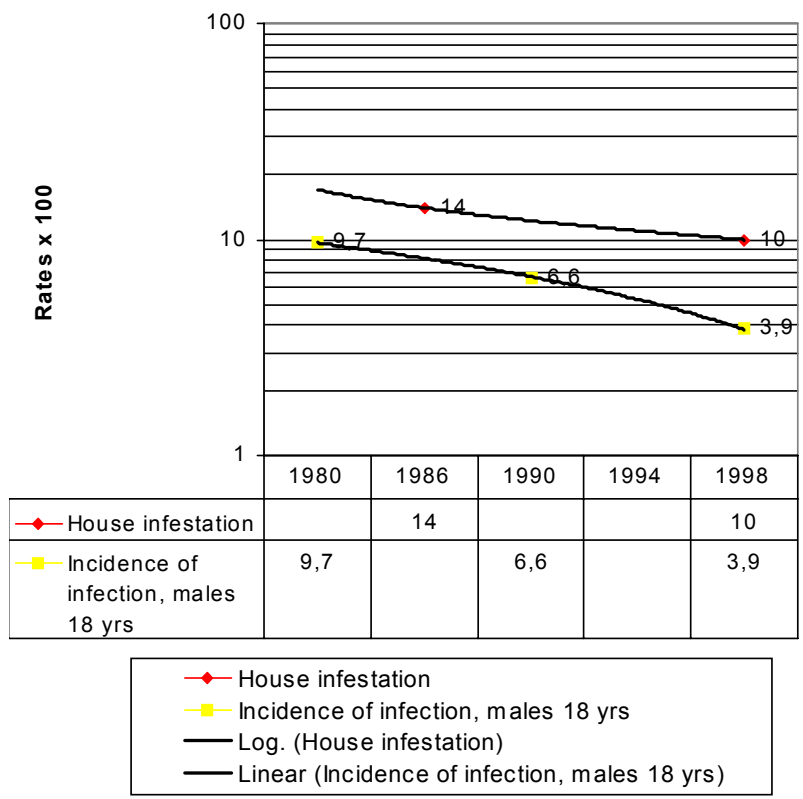

Source: Control of Chagas Disease, Report of the Expert Committee, WHO, TRS 905, Geneva 2002, p. 68-69

Fig. 6: Paraguay: interruption of transmission of Chagas diseae 1980-1998, Rates x 100

\section{URUGUAY (FIG. 7)}

T. infestans was the only intradomicile vector. Since 1997 this species has been eliminated from the intradomiciles in the whole country. In 1975 the endemic area comprised the departments of Artigas, Cerro Largo, Colonia, Durazno, Flores, Florida, Paysandú, Rio Negro, Rivera, Salto, San José, Soriano and Tacuarembó.

The house infestation rate dropped from $5.65 \%$ in 1983 to $0.30 \%$ in 1997 .

The interruption of vectorial and transfusional transmission was certified in 1997 and the whole country is under surveillance. There is $100 \%$ coverage of blood screening in blood banks.

The incidence of infection in the age group of 0-12 years was $0 \%$, which confirms the interruption of vectorial and transfusional transmission of Chagas disease in Uruguay since 1997 (WHO 1998a).

INITIATIVE OF THE ANDEAN COUNTRIES: EPIDEMIOLOGICAL TRENDS

In these countries there are 5 million infected individuals and 25 million are at risk of contracting the infection. This represents $27 \%$ of the prevalence of infected individuals of the whole continent.

As the vectors of Chagas disease in these countries are not strictly domiciliated, it is necessary to adapt and test the vector control strategies to the local entomological conditions.

In the Andean countries of Colombia, Ecuador, Perú, and Venezuela, the elimination of the vectorial transmission was launched at an Intergovernmental Meeting held in Bogotá in February 1997 where detailed country by country plans of action including annual goals, budgetary

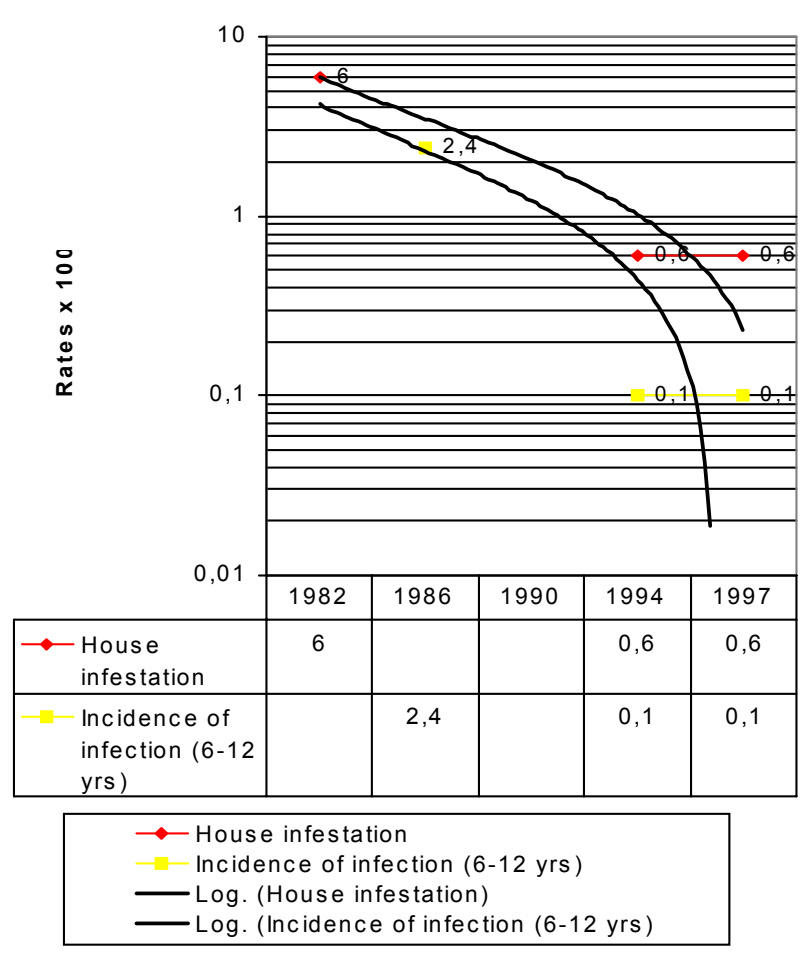

Source: WHO, Weekly Epidemiological Record, Geneva, 1998, 73: 1/2 1-4, and Report Ministry of Health, 1998

Fig. 7: Uruguay: interruption of transmission of Chagas disease 1982-1998, Rates x 100

needs, evaluation mechanisms and research needs were prepared (OPS/OMS 1997).

A second meeting of the Intergovernmental Commission was held in Maracay, Venezuela in March 1999, and in Guayaquil in 2002 where progress in control was reported as follows:

\section{COLOMBIA}

The main vector is $R$. prolixus but $T$. dimidiata has also been described as an effective $T$. cruzi vector.

It has been estimated that a $5 \%$ of the population living in the endemic areas is infected or approximately 700000 persons. The departments with higher infection rates are Arauca (21.1 x 100), Casanare (10), Santander (6.3), Norte de Santander (5.2), Boyacá (3.7), Cundinamarca (1.9) and Meta (1.7).

The screening in blood banks is mandatory since 1995 and there is $100 \%$ coverage in the whole country. In 2001 the prevalence in blood donors was $0.65 \%$ as compared with $2.1 \%$ in 1998 .

The preparatory phase of the national Chagas disease control program has been advanced and a map of the country featuring the risk municipalities has been prepared. The seroepidemiological survey in children 7-14 year old started in April 1999 and is now completed. The vector control activities with insecticide sprayings have been decentralized to the departments but there are no data available to monitor the impact of the control programs. 


\section{ECUADOR}

The main vector is $T$. dimidiata. The transmission occurs in the provinces of the Pacific coast including El Oro, Manabí and Guayas. It is estimated that between 30000 and 50000 persons are infected. However there are no data on prevalence of infection by age groups or on house infestation rates by province.

The preparatory phase of the national Chagas disease control program has been advanced. The law reorganizing the control program was issued in December 1998 and places the program under the Secretary of Tropical Medicine with specific functions and budget. The law for compulsory blood screening against $T$. cruzi was issued in August 1998. The seroprevalence of infected blood in blood banks for the whole country is $0.2 \%$.

PERÚ

The highest prevalence of human infection is found in the departments of Arequipa, Moquegua, Ica, and Tacna which comprise $8 \%$ of the total population of the country. The main vector is T. infestans and it is estimated that there are some 394000 houses infested with 24000 persons infected with the parasite. Acute cases are regularly reported from this endemic area which indicates active transmission. There are no screening programs in blood banks in spite of a prevalence of infected donations estimated in $2.4 \%$ in 1993.

\section{VENEZUELA (FIG. 8)}

The main vector is $R$. prolixus. The endemic area comprised, in 1987, 591 municipalities in an area of $700000 \mathrm{~km}^{2}$ with a population of 12 million.

The control program was officially established in 1966. The objective of the program was to interrupt intra-domestic transmission through vector control by insecticide spraying.

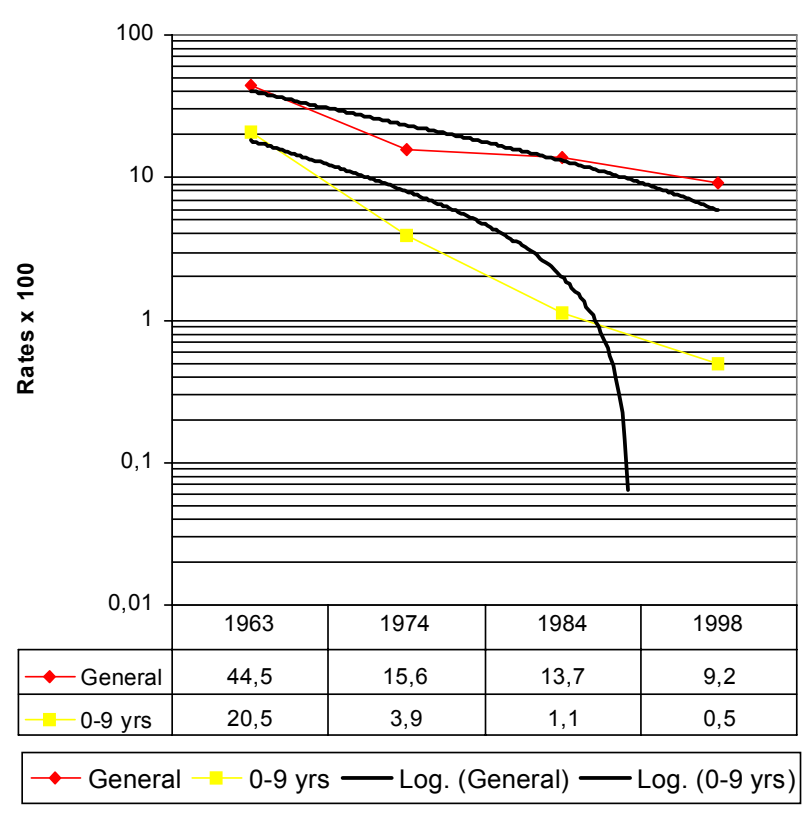

Source: Aché A, Matos AJ 2001. Interrupting Chagas disease transmission in Venezuela. Rev Inst Med Trop São Paulo 43: 37-43.

Fig. 8: Venezuela: infection by Trypanosoma cruzi in the general population and in the 0-9 year group, 1963-1998, Rates x 100
The program for improvement of rural housing, originally initiated in the 1960's, assists the rural inhabitants to substitute palm roofs, to plaster adobe walls and to cement earthen floors. In addition routine screening for T. cruzi in blood banks is mandatory since 1988 .

In children under 10 years, the figures of seroprevalence rates for $T$. cruzi infection have decreased steadily in the last four decades from $20.5 \%$, (1958-1968) to $3.9 \%$ (1969-1979), and further on to $1.1 \%$ (1980-1989), and to $0.8 \%$ at the present (1990-1999).

The incidence of infection in the age group 0-4 year old has been reduced by $90 \%$ to less than $1 \%$ from 1990 to 1999. The geographical distribution of T. cruzi transmission is restricted to the states of Portuguesa, Barinas, and Lara (WHO 1999b).

The prevalence of infected blood in blood banks has been reduced from $1.16 \%$ in 1993 to $0.78 \%$ in 1998 (Aquatella 1987).

\section{INITIATIVE OF THE CENTRAL AMERICAN COUNTRIES:} EPIDEMIOLOGICAL TRENDS

In these countries there are 2 million infected individuals and 26 million are at risk of contracting the infection. This represents $11 \%$ of the prevalence of infected individuals of the whole continent.

As the vectors of Chagas disease in these countries are not strictly domiciliated, it is necessary to adapt and test the vector control strategies to the local entomological conditions.

In the Central American countries, Belize, Costa Rica, El Salvador, Guatemala, Honduras, México, Nicaragua, and Panamá, progress in blood banks control is also proceeding well and all of them except one have issued legislation for compulsory blood screening against blood infected by T. cruzi.

Similarly, the elimination of the vectorial transmission was launched at an Intergovernmental Meeting held in Tegucigalpa, in October 1997, where detailed country by country plans of action including annual goals, budgetary needs, evaluation mechanisms and research needs were prepared (OPS/OMS 1997).

Further follow up meetings of the Intergovernmental Commission have been held in Guatemala city in 1998, in Managua, Nicaragua in 1999, in San Salvador, El Salvador in 2000, Panamá in 2001, and Tegucigalpa in 2002.

\section{BELIZE}

The only vector species of epidemiological importance is T. dimidiata, but is restricted to the wild environment. There are sporadic reports of insect adults attracted by light that are frequently found in the periphery of the cities and villages. The seroprevalence in the general population is very low and the seropositives found are migrants from neighboring countries. The screening of blood banks has 100\% coverage and the prevalence among blood donors in 2000 was $0.5 \%$.

\section{COSTA RICA}

The main vector is T. dimidiata. The vectors are found in the central plain, extending primarily to the Northwest and Southwest regions of the country. Seroprevalence of $1.94 \%$ was found in some blood banks of the country that 
participated in one study in 2000. A recent survey carried out in the Heredia province in 2001 in school children, $7-12$ year-old showed an infection rate of $0.2 \%$. Chagas disease is not considered a public health problem (OPS/ OMS 2001).

\section{EL SALVADOR}

T. dimidiata is the main vector. $R$. prolixus was detected in the country in the 1980 's, but this species disappeared from El Salvador in the last decade. T. dimidiata is the only vector currently detected in all departments with a house infestation rate of $21 \%$ in the dwellings in rural areas and in the small or medium townships. In 2000 the prevalence of the infection in school children $7-14$ years was $0.3 \%$ and $2.1 \%$ in the population older than 14 years.

The blood screening coverage was $100 \%$ in 2000 when the prevalence of infected blood was $2.48 \%$. The vector control program treated in that year $67.3 \%$ of infested dwellings in areas where there is co-existence of infestation by anophelins and triatomines.

\section{GUATEMALA}

T. dimidiata is found in 18 of the 22 departments and $R$. prolixus in 5 departments. The infestation rate varies from 12 to $35 \%$. The infection rate in school children in the 5 most endemic departments, namely, Zacapa, Chiquimula, Jalapa, Jutiapa, and Santa Rosa was $4.9 \%$ in a survey carried out in 2000 . There is a poor blood bank control system and prevalence of seropositive blood donations in 2000 was $0.84 \%$.

Vector control activities are carried out by the control program of the Ministry of Health in the mentioned departments with highest house infestation rates (OPS/ OMS 2001).

\section{HONDURAS}

The main vector $R$. prolixus is present in $11 \mathrm{de}-$ partments of the country and the second vector $T$. dimidiata is present in 16 departments. Vectors are present in the departments of Choluteca, Comayagua, Copan, Francisco Morazan, Intibuca, Lempira, Ocotepeque, Olancho, El Paraiso, La Paz, Santa Barbara, and Yoro. In 1983, the highest infection rates were found in the western and eastern departments and in the Southern region. About half of the population is estimated to be at risk. Infection rates of $32 \%$ or more in the vectors have been reported. The most frequent clinical manifestation is cardiopathy.

Vector control activities are carried out in 6 of the 9 Health Regions of the country.

A recent seroepidemiological survey carried out in areas under chemical control in children aged less than 5 years was $0.36 \%$ and in school children $7-14$ years was $3.3 \%$.

The coverage of the control of transfusional transmission is $100 \%$ and the national seroprevalence in blood donors in 2000 was $1.53 \%$ as compared to $11 \%$ in 1985 (OPS/OMS 2001).

\section{MÉXICO}

Vectors and infected mammals are found in the states of Chiapas, Guanajuato, Guerrero, Hidalgo, Jalisco, México, Michoacan, Morelos, Nayarit, Oaxaca, Puebla,
Sonora, Yucatan, and Zacatecas. The prevalence of the disease is highest in the Pacific coast states from Chiapas to Nayarit, in the Yucatan peninsula, and in some areas of the central part of the country. Although most of the human infections and clinical forms in México are considered to be mild, there have been recent reports of some cases of mega viscera. México has not introduced routine screening for T. cruzi in blood banks where 850000 donations are made every year and where around 12760 units of blood could be infected.

There is no vector control program although there is a renewed interest of the health authorities to organize national and state vector control activities.

\section{NICARAGUA}

T. dimidiata is present in 14 of 17 departments of the country and $R$. prolixus in 5 departments. The control of transfusional transmission is made in $70 \%$ of the blood banks with a prevalence of infected blood of $0.33 \%$. A seroepidemiological survey carried out in 2000 in school children showed a prevalence rate of $3.3 \%$ in this age group (OPS/OMS 2001).

\section{PANAMÁ}

The main vector is $R$. pallescens found inside the dwellings of the Chorrera district. This vector is present also in palms in the wild environment. T. dimidiata is also an important vector. There is no compulsory screening in blood banks or vector control programs.

\section{GOAL-ORIENTED RESEARCH}

The first Scientific Working Group in 1978 identified the research priorities that corresponded to the many questions that at the time lacked a scientific answer, in the fields of epidemiology and geographical distribution of the infection and disease; clinical pathology and evolution of the infection and disease; immunological mechanisms of the pathogenesis of the chronic lesions; development of better drugs; entomology and development of new vector control tools; variations of the parasite populations and molecular biology of the host-parasite interactions.

Since the inception in 1979 of the Steering Committee on Chagas Disease of the Special Program for Research and Training in Tropical Diseases of the World Health Organization (TDR), the objective was set to promote and finance research aimed at the development of new methods and tools to control this disease.

The well known research institutions in Latin America were the key elements of a world wide network of laboratories that received - on a competitive basis modest financial support for projects in line with the priorities established. The average annual research grant was around US\$25000.

The time line of the different milestones that were answering successively and logically the above questions and that made inputs in the development of practical solutions for diagnosis of the infection and disease control are featured in Table VIII.

It is interesting to note in this time line that research influenced and established working alliances with other actors such local industry for the development of diagnostic methods and vector control tools. 
TABLE VIII

The time line towards the interruption of transmission of Chagas disease, 1980-2001

\begin{tabular}{lll}
\hline Years & Phase & Studies/Processes \\
\hline 1980-1989 & Research & 1980-1985: prevalence cross-sectional studies on human infection and house infestation in \\
& & nine countries are carried out (PAHO 1974, Camargo et al. 1984, Schenone 1985, Reyes \\
& Lituma 1984, Ponce 1984, Lopez 1985, Cordova 1980, Salvatella et al. 1989, Acquatella \\
& 1987, Valencia 1990, Marinkelle 1976, Zeledón 1976, Cedillos 1975, Matta 1985, Sousa \\
& 1985) \\
& 1985: standardization of serological techniques and creation of a continental network of
\end{tabular}
reference laboratories (Camargo 1986)

1985-1990: follow-up prospective studies on the course of human infection (Coura 1983, Pereira 1985, Maguire 1987, Mota 1990, Arribada 1986)

1986-1988: cloning of parasite genome and production of defined antigens for improvement of diagnostic techniques (Peterson et al. 1986, Moncayo \& Luquetti 1990)

1990-1993 Industrial production Industrial production of kits for blood banks control in Argentina and validation Development of new tools for vector control (Oliveira Filho 1988, UNDP/WORLD BANK/WHO 1998a, b)

Multi country field studies for evaluation of new vector control tools (Oliveira Filho1997)

Industrial production of paints, canisters and sensor boxes in Argentina and Brazil (Zerba 1988)

1991-2001 Public health 1991: initiative of the Southern Cone countries is launched (Schmunis et al. 1996, 1997)

policy development 1997: initiatives of the Andean countries and the Central American countries are launched (OPS/OMS 1997)

1997: Uruguay declared free of vectorial and transfusional transmission of Chagas disease (WHO 1998a, UNDP/WORLD BANK/WHO 1998a)

1998: the 51st World Health Assembly endorses the goal for elimination of transmission of Chagas disease on the American continent in 2005 (WHO 1998b)

1999: treatment of the early chronic phase in children 7-11 year old, adopted as public health policy (PAHO/WHO 1999)

1999: Chile declared free of vectorial and transfusional transmission of Chagas disease (WHO 2000a)

2000: Brazil declared free of vectorial transmission of Chagas disease (WHO 2000b)

It is also worth noting that research was instrumental in the development of public health policy to attain the final goal of interrupting the transmission of Chagas disease and that this was possible by the engagement of the governments of the affected countries in organizing and financing with their own national funds the control programs.

The Expert Committee on the Control of Chagas Disease considered that given the advanced level of control of Chagas disease, the most important future research priorities should focus on field operational research for better planning of control activities, costeffectiveness of interventions and assessment of impact of control interventions. Regarding blood banks, research is centered on standardization and improvement of screening tests, evaluation of sensitivity and specificity of new screening tests and cost analysis of multiple blood bank screening (WHO 2002).

Other research lines to be pursued include: (1) analytical epidemiological case-control studies with standardized protocols to be carried out in different countries to identify factors related to the parasite, the host, and the environment that are responsible for the varied clinical forms of the disease; (2) development of prognostic markers to study the evolution of the indeterminate form into cardiac or digestive forms of the disease; and (3) studies on the prevalence and incidence of congenital transmission and the parasite strains involved.

Finally, the information generated by the $T$. cruzi genome project (UNDP/WORLD BANK/WHO 1994) should be used for the search of new targets for drug development, identification of the components of hostparasite interaction, studies on biological properties of parasite strains and drug resistance.

\section{REFERENCES}

Acquatella H 1987. Encuesta epidemiológica en sujetos con serología positiva para enfermedad de Chagas. Ciencia y Tecnología de Venezuela 4: 185-200.

Akhavan D 1997. Analysis of Cost-effectiveness of the Chagas Disease Control Program, Ministry of Health, National Health Foundation, Brasília. 
Arribada AC, Apt W, Ugarte JM 1986. A four-year follow up survey of chagasic cardiopathy in Chile. PAHO Bull 20: 245-266.

Camargo M, Segura EL, Kagan IG 1986. Three years of collaboration on the standardization of Chagas disease serodiagnosis: an appraisal. PAHO Bull 20: 233-244.

Camargo M, Silva GR, Castillo EA, Silveira AC 1984. Inquérito sorológico da prevalência de infecção chagásica no Brasil 1975/80. Rev Inst Med Trop São Paulo 26: 192-204.

Carrasco R 1990. Prevalence of Trypanosoma cruzi infection in blood banks of seven departments of Bolivia. Mem Inst Oswaldo Cruz 85: 69-73.

Cedillos RA 1975. Chagas disease in El Salvador. PAHO Bull 9: $135-141$

Cerisola A 1972. Muestreo serológico para la enfermedad de Chagas en conscriptos de la clase 1951. Rev Paraguaya Microbiol 7: 90.

Chagas C 1909. Nova tripanozomiase humana. Estudos sobre a morfolojía e o ciclo evolutivo de Schizotrypanum cruzi n.gen., n.sp., ajente etiolójico de nova entidade morbida do homen. Mem Inst Oswaldo Cruz 1: 159-218.

Cordova E 1980. Enfermedad de Chagas en el Sur del Perú. Bol Peruano Parasitol 2: 46-50.

Coura JR, Abreu LL, Pereira JB, Willcox HPF 1985. Morbidade da doença de Chagas. IV. Estudo longitudinal de dez anos em Pains e Iguatama, Minas Gerais, Brasil. Mem Inst Oswaldo Cruz 80: 73-80.

Coura JR, Anunziato N, Willcox HPF 1983. Morbidade da doença de Chagas. I. Estudo de casos procendentes de vários estados do Brasil, observados no Rio de Janeiro. Mem Inst Oswaldo Cruz 78: 363-372.

Dias JCP, Brener Z 1984. Chagas disease and blood transfusion. Mem Inst Oswaldo Cruz 79(Supl.): 139-147.

Franca ME 1986. Chagas disease in Uruguay in the last twenty years. Rev Méd Uruguay 2: 125-131.

Grant IH, Gold JW, Wittner M 1989. Transfusion-associated acute Chagas disease acquired in the United States. Ann Intern Med 111: 849-851.

Guhl F 1987. Rastreo seroepidemiológico de donantes de sangre chagásicos en una zona endémica (Norte de Santander, Colombia). Rev Latinoam Microbiol 29: 63-66.

Kirchhoff L, Gamm AA, Gilliam FC 1987. American trypanosomiasis (Chagas disease) in Central American immigrants. Am J Trop Med Hyg 82: 915.

Liendo F, Salinas P, Contreras MC 1985. Enfermedad de Chagas en Chile. Sectores urbanos. XIII. Prevalencia de infección por Trypanosoma cruzi en donantes de sangre del sector sur del área metropolitana de Santiago. Bol Chileno Parasitol 40: $82-84$.

López L 1985. Encuesta Serológica de Prevalencia de la Enfermedad de Chagas en Paraguay, Ministerio de Salud, SENEPA, Informe de Proyecto, Asunción, Paraguay.

Maguire JH, Hoff R, Sherlock I 1987. Cardiac morbidity and mortality due to Chagas disease: prospective electrocardiograph study of a Brazilian community. Circula-tion 75: 1140-1145.

Marinkelle C 1976. Aspects of Chagas disease in Colombia. In American Trypanosomiasis Research, PAHO Scientific Publication 318, Washington DC, p. 340-346.

Marzochi MCA 1981. Chagas disease as an urban problem. Cad Saúde Púb 2: 7-12.

Matta V 1985. Seroepidemiología de la enfermedad de Chagas en Guatemala. Memorias VII Congreso Centroamericano de Microbiología, San José, Costa Rica, p.17.

Mercosur 1991. Reunión de Ministros de Salud del Mercosur, Brasília, Junio, Resolución 04-3-CS.

Ministry of Health, Funasa 1999. Report to the VIII Meeting of the Intergovernmental Commission of the Southern Cone Initiative, Tarija, Bolivia, 16-18 March.

Ministerio de Salud Argentina 2002. Informe del Ministerio de Salud, Buenos Aires.

Moncayo A 1997. Progress towards elimination of transmission of Chagas disease in Latin America. WHO Statistics Quarterly 50: 195-198.

Moncayo A, Luquetti A 1990. Multicentre double blind study for evaluation of Trypanosoma cruzi defined antigens as diagnostic reagents. Mem Inst Oswaldo Cruz 85: 489-495.

Mota EA, Guimaraes AC, Santana O 1990. A nine year prospective study of Chagas disease in a defined rural population in Northeast Brazil. Am J Trop Med Hyg 42: 429-440.

Nickerson P, Orr P, Schroeder ML 1989. Transfusion-associated Trypanosoma cruzi infection in a non-endemic area. Ann Intern Med 111: 851-853.

Oliveira Filho AM 1988. Development of insecticide formulations and determination of dosages and application schedules to fit specific situations. Rev Argent Microbiol 20 (Supl.): 39-48.

Oliveira Filho AM 1997. Uso de nuevas herramientas para el control de triatominos en diferentes situaciones entomológicas en el Continente Americano. Rev Soc Bras Med Trop 30: 41-46.

OPS/OMS 1997. Informes de las Iniciativas de los Países Andinos, Bogotá, Febrero y Tegucigalpa, Octubre.

OPS/OMS 2001. Informe de la IV Reunión de la Comisión Intergubernamental de la Iniciativa de Centro América, Ciudad de Panamá.

PAHO 1974. Aspectos clínicos de la enfermedad de Chagas. Bol Of Sanit Panam 76: 141-155.

PAHO 1998a. Report of the VI Meeting of the Intergovernmental Commission of the Southern Cone Initiative, Santiago, Chile, March 1997, OPS/HPC/HCT/98.102, Washington DC, p. 33-36.

PAHO 1998b. Report of the VII Meeting of the Intergovernmental Commission of the Southern Cone Initiative, Buenos Aires, Argentina, March, OPS/HPC/HCT/98.114, Washington DC.

PAHO/WHO 1999. Treatment of the early chronic phase of Chagas disease in children and adults. Report of an Expert Group, Washington DC.

Pereira JB, Willcox HP, Coura JR 1985. Morbidade da doença de Chagas. III. Estudo longitudinal de seis anos, em Virgem da Lapa, MG, Brasil. Mem Inst Oswaldo Cruz 80: 163171.

Pereira MG 1984. Characteristics of urban mortality from Chagas' disease in Brazil's Federal District. Bol Of Sanit Panam 96: 213-221.

Pérez A, Segura EL 1989. Blood transfusion and transmission of Chagas infection in Argentina. Rev Argent Transfusión 15: 127-132.

Peterson DS, Wrightsman RA, Manning JE 1986. Cloning of a major surface-antigen gene of Trypanosoma cruzi and identification of a nonpeptide repeat. Nature 322: 566-568.

Pless M, Juranek D, Kosarsky P 1992. The epidemiology of Chagas' disease in a hyper endemic area of Cochabamba, Bolivia: a clinical study including electrocardiography, seroreactivity to Trypanosoma cruzi, xenodiagnosis, and domiciliary triatomine distribution. Am J Trop Med Hyg 47: 539-546.

Ponce C 1984. Prevalencia de la Enfermedad de Chagas en Honduras, Ministerio de Salud, Tegucigalpa, Honduras.

Ponce C, Ponce E 1987. Infección por Trypanosoma cruzi en donantes de sangre de diferentes hospitales de Honduras, 
8th Latin American Congress of Parasitology, Guatemala, November, p. 260.

Reyes Lituma V 1984. Estudio de Prevalencia de Enfermedad de Chagas en Ecuador, Ministerio de Salud, Programa de Control de Vectores, Guayaquil, Ecuador.

Salvatella R, Calegari L, Casserone S 1989. Seroprevalencia de anticuerpos contra Trypanosoma cruzi en 13 departamentos del Uruguay. Bol Of Sanit Panam 107: 108-117.

Schenone H 1985. Enfermedad de Chagas en Chile. Sectores rurales y periurbanos del área de endemo-enzootia. Relaciones entre condiciones de la vivienda, infestación triatomídea domiciliaria e infección por Trypanosoma cruzi del vector, del humano y de mamíferos domésticos. 19821985. Bol Chil Parasitol 40: 58-67.

Schmunis GA 1991. Trypanosoma cruzi, the etiologic agent of Chagas' disease: status in the blood supply in endemic and no endemic countries. Transfusion 31: 547-557.

Schmunis GA, Zicker F, Moncayo A 1996. Interruption of Chagas' disease transmission through vector elimination. The Lancet 9035: 1171.

Segura EL, Perez A, Yanovsky JF 1985. Decrease in the prevalence of infection by Trypanosoma cruzi (Chagas disease) in young men of Argentina. Bull PAHO 19: 252264.

Sousa O 1985. Encuesta Serológica de Prevalencia de la Enfermedad de Chagas en Panamá, Laboratorio de Biología, Universidad de Panamá, Informe de Proyecto, Ciudad de Panamá.

Souza AG, Wanderley DMV, Buralli 1984. Consolidation of the control of Chagas disease vectors in the state of São Paulo. Mem Inst Oswaldo Cruz 79 (Supl.): 125-131.

Sucam, Ministerio da Saúde 1987. Alguns aspectos econômicos e de custo-benefício em doença de Chagas no Brasil, Informações Epidemiológicas, Sucam, V. 54.

UNDP/WORLD BANK/WHO 1987. Special Programme for Research and Training in Tropical Diseases, Eighth Programme Report, Geneva, p. 92

UNDP/WORLD BANK/WHO 1991. Special Programme for Research and Training in Tropical Diseases, Eleventh Programme Report, Geneva, p. 67

UNDP/WORLD BANK/WHO 1994. Special Programme for Research and Training in Tropical Diseases, Trypanosoma cruzi genome project, (http://www.dbbm.fiocruz.br/ TcruziDB/index.html)

UNDP/WORLD BANK/WHO 1998a. Special Programme for
Research and Training in Tropical Diseases. TDR Newsletter 56: 6.

UNDP/WORLD BANK/WHO 1998b. Special Programme for Research and Training in Tropical Diseases, Third External Review, Final Report, p. 27 and Reference Document nr 5.

Urbina A 1991. Serologic prevalence of infection with T. cruzi in blood donors in Costa Rica, Abstracts VII Congreso Centroamericano de Microbiología y Parasitología nr 18, p. 204.

Valencia A 1990. Investigación Epidemiológica Nacional de la Enfermedad de Chagas, Ministerio de Previsión Social y Salud Pública, La Paz, Bolivia, PL-480 Title III.

Velasco Castrejón O, Guzmán Bracho C 1986. Importance of Chagas disease in México. Rev Latinoam Microbiol 28: 275 283.

WHO 1994. Chagas disease, elimination of transmission in Uruguay. Weekly Epidemiol Rec 6: 38-40.

WHO 1995. Chagas disease, interruption of transmission in Chile. Weekly Epidemiol Rec 3: 13-16.

WHO 1996. Chagas disease, progress towards elimination of transmission in Argentina. Weekly Epidemiol Rec 2: 12-15.

WHO 1997. Chagas disease, interruption of transmission in Brazil. Weekly Epidemiol Rec 2: 1-5.

WHO 1998a. Chagas disease, interruption of transmission in Uruguay. Weekly Epidemiol Rec 2: 1-4.

WHO 1998b. 51st World Health Assembly, Resolution WHA51.14.

WHO 1999a. Chagas disease, interruption of transmission in Chile. Weekly Epidemiol Rec 2: 9-11.

WHO 1999b. Chagas disease, progress towards interruption of transmission in Venezuela. Weekly Epidemiol Rec 35: 289-292.

WHO 2000a. Chagas disease, certification of interruption of transmission in Chile. Weekly Epidemiol Rec 2: 10-12.

WHO 2000b. Chagas disease, interruption of transmission in Brazil. Weekly Epidemiol Rec 19: 153-155.

WHO 2002. Report of the Expert Committee on the control of Chagas disease, Technical Report Series 905, Geneva, p. 85.

Zeledón R 1976. Epidemiological pattern of Chagas disease in an endemic area of Costa Rica. Am J Trop Med Hyg 24: 214-225.

Zerba EN 1988. Development of new insecticides and synergistic formulations of the Chagas disease vector control. Rev Argent Microbiol 20(Supl.): 25-31. 